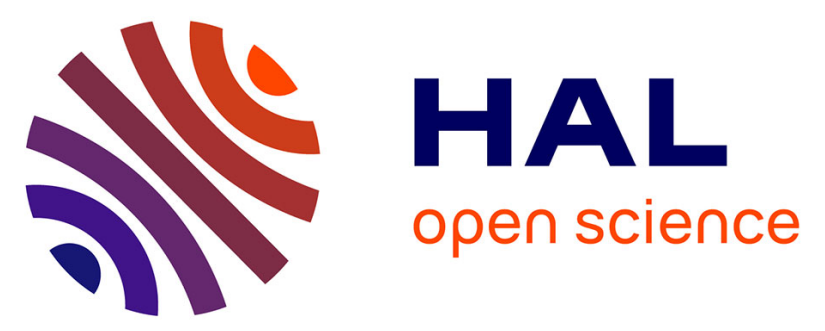

\title{
Methoni Mw 6.8 rupture and aftershocks distribution from a dense array of OBS and land seismometers, offshore SW Hellenic subduction
}

Maria Sachpazi, Vasilis Kapetanidis, Marinos Charalampakis, Mireille Laigle, Edi Kissling, Anna Fokaefs, Elena Daskalaki, Ernst Flueh, Alfred Hirn

\section{To cite this version:}

Maria Sachpazi, Vasilis Kapetanidis, Marinos Charalampakis, Mireille Laigle, Edi Kissling, et al. Methoni $\mathrm{Mw} 6.8$ rupture and aftershocks distribution from a dense array of OBS and land seismometers, offshore SW Hellenic subduction. Tectonophysics, 2020, 796, pp.228643. 10.1016/j.tecto.2020.228643 . hal-03083046

\section{HAL Id: hal-03083046 https://hal.science/hal-03083046}

Submitted on 22 Dec 2020

HAL is a multi-disciplinary open access archive for the deposit and dissemination of scientific research documents, whether they are published or not. The documents may come from teaching and research institutions in France or abroad, or from public or private research centers.
L'archive ouverte pluridisciplinaire HAL, est destinée au dépôt et à la diffusion de documents scientifiques de niveau recherche, publiés ou non, émanant des établissements d'enseignement et de recherche français ou étrangers, des laboratoires publics ou privés. 
1 Methoni Mw 6.8 rupture and aftershocks distribution from a dense array of OBS

2 and land seismometers, offshore SW Hellenic subduction

4 Maria Sachpazi $^{\mathrm{a} *}$, Vasilis Kapetanidis ${ }^{\mathrm{b}}$, Marinos Charalampakis ${ }^{\mathrm{a}}$, Mireille Laigle ${ }^{\mathrm{c}}$, Edi Kissling ${ }^{\mathrm{d}}$, $5 \quad$ Anna Fokaefs ${ }^{\mathrm{a}}$, Elena Daskalaki ${ }^{\mathrm{a}}$, Ernst Flueh $^{\mathrm{f}}$, Alfred Hirn ${ }^{\mathrm{g}}$

6 anstitute of Geodynamics, National Observatory of Athens, Athens, Greece,

$7 \quad{ }^{b}$ Department of Geophysics-Geothermics, Faculty of Geology and Geoenvironment, National and 8 Kapodistrian University of Athens, Athens, Greece

9 'Université Nice Sophia Antipolis, CNRS, IRD, Observatoire de la Côte d'Azur, Géoazur, Valbonne, 10 France,

$11{ }^{d}$ Institute of Geophysics, ETH Zurich, Zürich, Switzerland, ${ }^{f}$ GEOMAR Helmholtz Centre for Ocean Research, Kiel, Germany

${ }^{g}$ Institut de Physique du Globe de Paris, Sorbonne Paris Cité, Paris VII - Denis Diderot University,

14 Paris, France

$15 *$ Corresponding author: m.sachp@noa.gr

\section{Abstract}

Along the south-western offshore Hellenic subduction zone, the overriding Aegean upper plate above the Mediterranean oceanic lithosphere generates uncommon large earthquakes on the offshore megathrust fault. The largest subduction thrust event, for half a century, has been the 14 February 2008 Methoni earthquake $(\mathrm{Mw}=6.8)$ that occurred offshore of the southwest coast of Peloponnesus.

We conducted micro-seismicity experiments around the rupture area and forearc domain -between Peloponnesus and Crete- using ocean bottom seismometers (OBS) jointly with land-based seismological stations. Our first experiment in 2006, had revealed an association of the Matapan Trough, a 400-km-long forearc basin, with local seismicity clustering and a possible gap in activity over the later Methoni rupture area. Here we present new data of post-Methoni seismic activity, recorded during a time-span of 11 months, beginning in October 2008 within the period of proposed 
afterslip on the megathrust, by an extended and dense seismic array consisting of up to 33 OBS. A minimum 1D velocity model was constructed for the region to provide better constraints on absolute locations and double-difference relocation was applied to produce an enhanced image of the spatial distribution of hypocenters. The high resolution earthquake locations confirm correlation of the Matapan Trough with local seismicity as a regional feature, also filling up the previously observed gap. Over the Methoni rupture area, we constrain seismicity to be located mainly within the upper plate. Hypocenters are also resolved above the updip and downdip edges of the rupture area, respectively. Seismic activity provides hints of upper plate structures which were activated in response to post-seismic deformation spreading within the forearc crust. Our findings highlight the characteristics of a megathrust domain which is related with a highly deformable overriding plate and controlled by a segmented lower plate topography.

Keywords: Methoni earthquake, SW Hellenic subduction, Aftershocks, Afterslip, Upper plate deformation. earthquake of the Mediterranean area, a magnitude 8-8.5 tsunamigenic event in 365 AD (Papazachos and Papazachou, 2003; Stiros and Papageorgiou, 2001). Yet, only five interplate events with moderate magnitudes ( 6.5-7.0) occurred during the instrumental period (1965-present) (Fig.1a), and only three such events occurred during the earlier period in the $19^{\text {th }}$ to early $20^{\text {th }}$ century (Papazachos and Papazachou, 2003).

On 14 February 2008, a $\mathrm{Mw}=6.8$ subduction thrust event occurred, $50 \mathrm{~km}$ offshore of the southwest coast of Peloponnesus, known as the Methoni earthquake (Fig.1a). Despite its moderate magnitude, it is the largest event, for half a century, in the $400 \mathrm{~km}$ long part of the Hellenic subduction, from the Cephalonia Transform Fault CTF) to Crete. The Methoni event ruptured a 30 $\mathrm{km}$ x $30 \mathrm{~km}$ thrust area along the plate interface between the southwestward overriding Aegean plate and the Ionian oceanic crust (Roumelioti et al., 2009). Geodetic measurements (continuous GPS time series) have shown that post-seismic slip continued for $\sim 3$ years and the total displacement is of 
56 comparable magnitude as co-seismic slip (Howell et al., 2017a). The post-seismic displacements are

57 attributed to afterslip on the subduction interface, distributed over a $100 \mathrm{kmX} 120 \mathrm{~km}$ wide region

58 including the co-seismic rupture with its greatest values observed where elevated levels of seismicity

59 were detected following the earthquake (Howell et al., 2017a) (Fig.1b).

60 Afterslip occurs as a widespread post seismic process in subduction zones, complementary to the

61 large coseismic slip zone (e.g. Cattania et al 2015; Yagi et al., 2003; Ozawa et al., 2012) and it is

62 considered as playing an important role in promoting aftershock earthquakes on the subduction 63 interface (Hsu et al., 2006) and the upper plate as well (Hayes et al., 2014a).

64 In this paper, we present observations collected from 9 to 21 months after the Methoni earthquake 65 by a dense array of Ocean Bottom Seismometers (OBS) and seismic stations in the close onshore. We 66 investigate post-Methoni seismicity with respect to the shape and extension of the rupture area as well 67 as the widely distributed post seismic deformation. We combine seismic activity, focal mechanisms 68 and structural data to characterize the pre-, co- and post-seismic behavior of the megathrust boundary 69 over the Methoni rupture area, as well as the regional seismicity. 


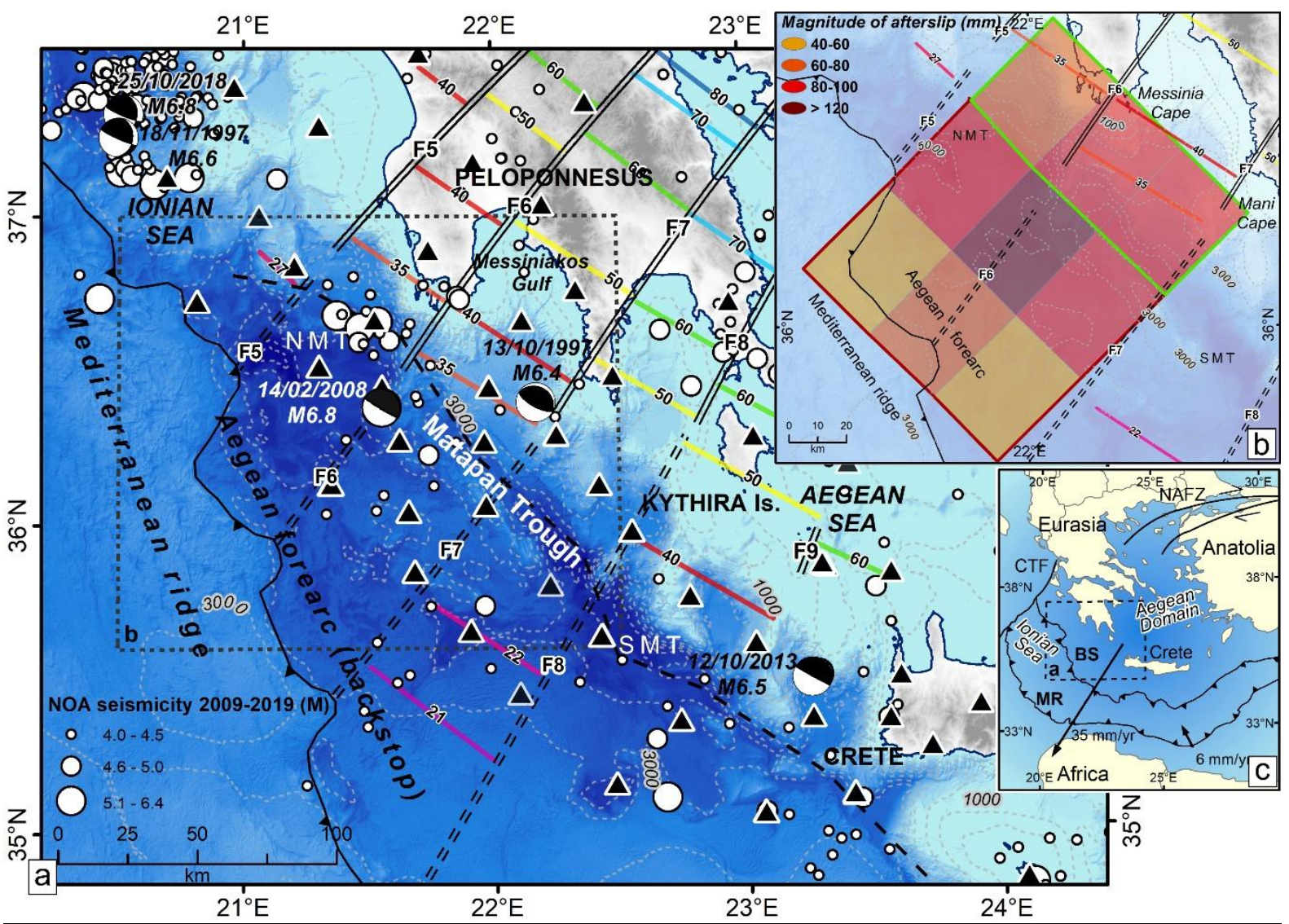

Fig.1. SW Hellenic subduction region. Background bathymetric data, here and in subsequent figures are from Brosolo et al., 2012 and Vitard et al., 2015. (a) Black triangles: the onshore-and offshore seismological stations of the Thales Was Right "TWR" project. The 14 February 2008 Mw 6.8 Methoni earthquake location (indicated by its CMT Harvard focal mechanism beachball) is from Sachpazi et al. (2016b). Focal mechanisms for subduction thrust events of Mw 6.0 or greater during the instrumental period are from the CMT Harvard catalogue, except for the Crete 2013 event (Howell et al., 2017a). Earthquake locations of these events are from the National Observatory of Athens (NOA) catalogue. Here and in subsequent figures: Double-lines: Slab along-dip faults from Sachpazi et al. (2016a), labelled F5 to F9. Dashed double lines: offshore extensions of mapped onshore slab faults from Sachpazi et al. (2016b). Colored lines: isobaths of slab Moho with depth denoted in kilometres (Sachpazi et al., 2016a,b). NMT and SMT: the Northern and Southern Matapan Trough. Black barbed line: outer limit of backstop, thrust contact of the accretionary wedge of the Mediterranean Ridge over it. Black dashed NW-SE trending line: Inner limit of the backstop at the transition between the Matapan Trough to the SW and the Hellenic continental margin to the NE from 
Le Pichon et al. (2019). (b) Distribution of post-seismic slip over the offshore forearc as afterslip according to geodetic data modeling (Howell et al., 2017a) with the higher $>0.2$ resolution area marked by a green rectangle. (c) Sketch of the Hellenic subduction zone in the wider East Mediterranean context with GPS-derived velocities with respect to Eurasia (Kahle et al., 2000). Black barbed lines with triangles pointing towards opposite directions represent the external limit of the Mediterranean Ridge (MR) over the Ionian oceanic basin and the outer limit of the backstop (BS) from SW to NE respectively oceanic lithosphere of the Mediterranean/Ionian Sea, at the edge of the African plate and the southwestwards fast advancing of the Aegean continental domain ( 4cm/yr) (Kahle et al., 2000; Nocquet 2012) (Fig.1c). The Africa/Europe convergence vector is highly oblique to the margin and responsible for strain partitioning at the backstop edge (Chamot-Rooke et al., 2005). concluding that the plate interface accommodates up to $80 \%$ of the convergence through aseismic slip (North, 1974; Jackson and McKenzie, 1988a,b; Baker et al., 1997; Shaw and Jackson, 2008; Shaw et al., 2010; Reilinger et al., 2010; England et al., 2016), with earthquakes of Mw 7 rupturing isolated locked patches (Howell et al., 2017a; Vernant et al., 2014). However, in the absence of offshore geodetic observations the size and location of these locked patches are poorly constrained.

108 Furthermore, local offshore seismicity is not sufficiently constrained by land-based permanent 109 stations to provide insight on the seismogenic patterns of the interplate thrust boundary or a robust 110 and well constrained velocity model for the area.

111 Local scale earthquake studies on the island of Crete with onshore seismological stations provided 112 constraints on the distribution of seismic activity associated with the subduction beneath southern 113 Crete (Meier al., 2004). For the region offshore southwest Crete and the southern Peloponnesus 114 however, hypocenters lack offshore constraints. A year and half before the 2008 Methoni earthquake, 115 in May-October 2006, we conducted a pilot study over that offshore domain by deploying 5 OBS 
116 jointly with coastal stations in order to better constrain the seismicity location. That study has

117 revealed that the recorded hypocenters along the $250-\mathrm{km}$ - long segment of the southwest Hellenic

118 subduction zone occur mostly at 10-15 km depth, in the upper plate's crust (Sachpazi et al., 2016b).

119 This first well-constrained local seismic activity was shown to correlate with an Aegean fore-arc 120 specific feature, the Matapan Trough (MT) which has not previously been considered as a seismically 121 active region.

122 This major $-400 \mathrm{~km}$ long- linear depression, reaching the greatest water depth $(5 \mathrm{~km})$ for the 123 Mediterranean Sea, has long been considered as the Hellenic plate boundary trench (e.g., Jongsma, 124 1977) and is still called the Hellenic Trench. It is a $4-5 \mathrm{~km}$ deep forearc basin which marks the 125 transition between the inner forearc to the NE and the backstop to the SW (Le Pichon et al., 2019, Part 126 2) (Fig.1a). Despite marine seismic studies, the tectonic origin of this bathymetric feature of the 127 Aegean plate remains controversial. Once the Mediterranean Ridge was recognized as an accretionary 128 prism (Le Pichon et al., 1982), Huchon et al. (1982) and Le Pichon et al. (1982) interpreted the 129 Matapan Trough as a narrow deep forearc basin. Based on Sea-Beam data and early seismic profiles,

130 Lallemant et al. (1994) proposed that the MT is dominated by the along-arc extension. Based on 131 seismic velocities and structure, and estimated time evolution of the Hellenic subduction zone, Le 132 Pichon and Lallemant (2002) proposed that the backstop consists of a pile of Hellenic nappes. Shaw et 133 al., 2010 considered instead the scarp of the Matapan Trough as the trenchward edge of the backstop 134 to the deformed accretionary prism. This scarp would be the surface expression of a reverse fault, 135 splaying off the deeper underlying thrust interface of the subduction zone. The authors propose that 136 this fault, rather than the seismically low coupled plate interface, would be the causative fault that 137 hosted the $365 \mathrm{AD} \mathrm{Mw}=8-8.5$ tsunamigenic mega-event.

138 The few low-angle thrust events of the instrumental period highlighting the seismogenic portion of 139 the mega-thrust subduction fault occurred mainly arcward of the Matapan Trough (Laigle et al., 2004; 140 Shaw et al., 2010). Even though the seismogenic interplate boundary lies offshore and is accessible by 141 seismic reflection profiling, its imaging was hindered by its significant depth (over $15 \mathrm{~km}$ ), the 142 presence of the sub-surface evaporites (Chaumillon et al., 1996 ; Reston et al., 2002b) plus the stacked 143 alpine nappes of the upper plate's crust (Le Pichon and Lallemant, 2002). 
144 Teleseismic receiver function (RF) imaging on a dense 2D seismic array has revealed the Moho of

145 the subducting plate, below the onshore forearc, to exhibit along-strike steps (Sachpazi et al., 2016a).

146 The authors showed that the slab is segmented into subducting panels by a series of nine along-dip

147 faults. Extending the imaging further offshore by 5 OBS, Sachpazi et al. (2016b) proposed that 148 segmentation continues below the $8-10 \mathrm{~km}$ thick backstop to its outer limit (Fig.1a). They further 149 suggested that these faults control the size and location of earthquakes in the megathrust boundary, 150 such as the Methoni earthquake. This event was recorded by a nearby dense land network (Thales Was 151 Right "TWR" Experiment) and hence could be located with the highest resolution ever obtained in 152 that area for an event of this order of magnitude (Sachpazi et al., 2016b). The Methoni earthquake was 153 initiated along the offshore prolongation of the intra-slab fault F6 (Fig.1a). Its focal mechanism shows 154 a typical subduction thrust event on a $\mathrm{N} 35^{\circ} \mathrm{E}$ dipping plane.

155 The source process, studied by teleseismic and regional broad band waveform modeling 156 (Roumelioti et al., 2009), showed that the rupture extended unilaterally towards the SE along the $\sim 2 / 3$ 157 of the F6F7 panel, in two areas of high coseismic slip (Fig.2a). Two hours after the mainshock, a large 158 interplate event $(\mathrm{Mw}=6.5)$ occurred at the southeastern border of the main rupture's slip extent. One 159 week later, another strong event $(\mathrm{Mw}=6.2)$ occurred in the overriding plate directly above the Mw 6.5 160 hypocenter with a strike slip mechanism. Significant aftershock activity continued within the 161 overriding plate over the next four months, but was manifested as a series of reverse faulting 162 earthquakes ( $\mathrm{M}_{\mathrm{w}}$ between 4.6 and 5.4) (Fig.2a). Their hypocenters were located across the remaining 163 eastern part of the F6F7 panel which has not slipped co-seismically. On the other hand, no such 164 significant aftershock activity occurred at the western part of the panel. The pronounced effect of this 165 strong activity on seismicity rate is visible as the large first peak in Fig.2b. After a relatively quiet 3166 months period, two bursts of activity mark the $2^{\text {nd }}$ phase of earthquake clustering and seismicity rate 167 increase which corresponds to the observations discussed in this paper. 


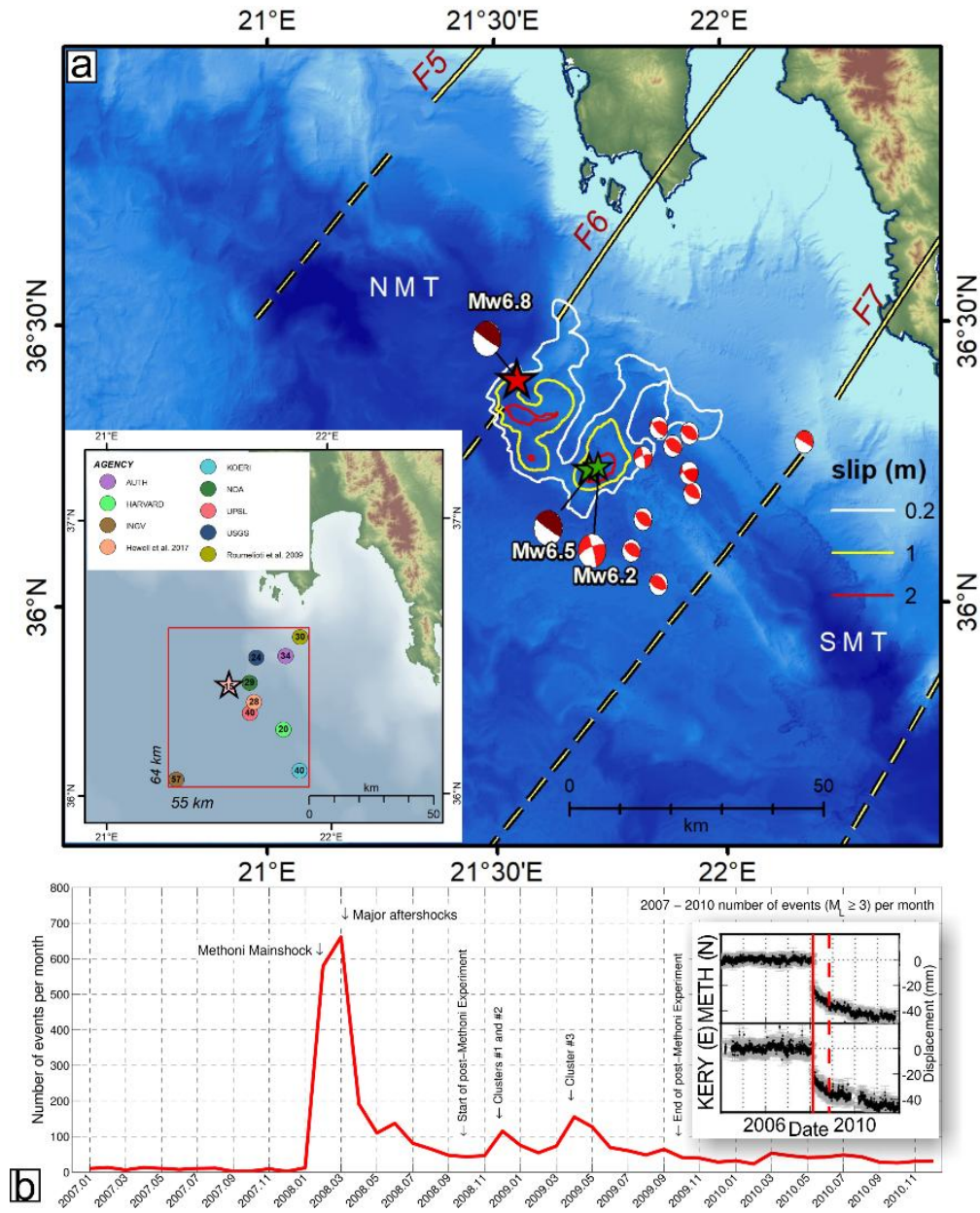

170 Fig. 2. Overview of the 14 February 2008 Methoni earthquake sequence and slip history. (a)

171 Coseismic slip distribution area after Roumelioti et al. (2009) with the epicenters of the mainshock

172 and stronger aftershocks $4.5 \leq \mathrm{Mw} \leq 6.5$ (February to June 2008) from Sachpazi et al. (2016b). The

173 mainshock, the $\mathrm{Mw}=6.5$ interplate aftershock and the $\mathrm{Mw}=6.2$ shallow aftershock locations are represented by stars. CMT (Harvard) focal solutions of the mainshock and the $\mathrm{Mw}=6.5$ aftershock are drawn with dark red beachballs placed in the position of the epicenters while other significant aftershocks are colored in light red. Inset map: Comparative map of the Methoni hypocenter locations

177 by various agencies (circles) and by Sachpazi et al. (2016b), (star) with focal depths (in km) denoted

178 by numbers inside the respective symbols. (b) Monthly seismicity rate of the area of Fig.2a, from

179 NOA earthquake catalogue during 1 year before and 3 years after the Methoni earthquake occurrence

180 (3.0 $\leq \mathrm{M} \leq 6.8$ ). Panel to the right side of $\mathrm{b}$ ) shows GPS time series of stations METH and KERY (north

181 -N- and east-E- component, respectively) from Howell et al. (2017a). The date of the start of our post-

182 Methoni experiment is marked by dashed red line. 
We deployed a total of 33 three-component ocean bottom seismometers (OBS) in the southwestern part of the Hellenic subduction zone, during a period of over 11 months, (October 2008-September 2009) (Fig.1a). The OBS array was complemented by 15 onshore instruments. We refer to this campaign as the "post-Methoni experiment", and to previous experiment (May 2006October 2006) as the "pre-Methoni experiment". Both campaigns were part of a major onshore/offshore experiment (“TWR” EU project 2006-2011), which also involved the collection of teleseismic data used for receiver function studies across the Peloponnesus (Sachpazi et al., 2016a) and its adjacent offshore domain (Sachpazi et al., 2016b). Observations from more than 2000 events were manually picked and the hypocenters were initially located using a simple 3-layer velocity model (Sachpazi et al., 2016b) and the Hypo71 code (Lee \& Valdes, 1989). To improve locations, we constructed a minimum 1D P-wave velocity model using the VELEST code (Kissling, 1995;

196 Kissling et al., 1994), which jointly inverts for the velocity model along with the respective station 197 delays and hypocenter coordinates using a damped least squares iterative inversion scheme. The 198 procedure was performed on a selected dataset of 1104 well-locatable events with at least 7 Pobservations and azimuthal gap $<180^{\circ}$. There are many fewer events with enough S-wave picks and small gap (146 events with at least $5 \mathrm{P}$ - and 5 S-wave picks on common stations, with gap $<180^{\circ}$ ) and their seismic ray coverage is very sparse over most of the study area. We regarded this S data set as too small and not adequate to allow the independent construction of an 1D velocity model for Swaves. The procedure of converging towards the final 1D P-velocity model with minimum RMS error, including a series of tests to assess the stability of the produced hypocentral solutions are analytically described in Section 1 of the supplementary material.

Our final 1D P-wave velocity model (Table 1) has a fairly constant velocity in the uppermost

$20728 \mathrm{~km}$ of the overriding crust (probably mixture of mostly upper continental crustal material with 208 some underplated material). Below that depth, the effect of the 2D dipping plate interface and the oceanic Moho becomes apparent. A more pronounced step in the velocity depth function would be 
210 expected if, across the study region, there was a Moho with some limited topography, appearing 211 roughly sub-horizontal on a regional scale, and well sampled by the available data. On the other

212 hand, if there is a consistently dipping Moho interface with limited 3D topography, the velocity

213 variation from normal crustal velocities to typical mantle velocities is expected to be spread across a

214 depth range more widely than typical for a Moho. Our final model supports the latter case for the 215 geometries in the study region.

216 We further reduce the relative location uncertainties in the post-Methoni 2008-2009 seismicity by 217 applying a double-difference relocation procedure. We incorporate the hypocenters and corrected 218 travel-times from the results of the minimum 1D model along with differential travel-times from 219 waveform cross-correlations (see supplementary material for a detailed description of the procedure).

220 Finally, we have taken advantage of the newly constructed 1D velocity model, including stationcorrections, where available, to relocate the pre-Methoni 2006 sequence as well, in order to discuss the results in conjunction with the relocated catalogue of the 2008-2009 experiment. The hypocentral location of the 2008 Methoni mainshock and major aftershocks are also revisited, in light of the new

224 velocity model.

226 Table 1: Final 1D P-wave velocity model for the study region. Note the typical continental crustal velocities down to $28 \mathrm{~km}$. Between that depth value and $43 \mathrm{~km}$ depth we obtain a velocity gradient reflecting the spatial variation of the depth of the Moho, which is dipping under the area (see text).

\begin{tabular}{cc}
\hline Depth $(\mathrm{km})$ & $\mathbf{V p}(\mathbf{k m} / \mathbf{s})$ \\
\hline-3.0 & 5.80 \\
5.0 & 5.90 \\
10.0 & 5.92 \\
15.0 & 6.26 \\
21.0 & 6.29 \\
28.0 & 6.93 \\
35.0 & 7.27
\end{tabular}




\begin{tabular}{rr}
\hline 43.0 & 7.95 \\
51.0 & 8.00 \\
75.0 & 8.10 \\
105.0 & 8.20
\end{tabular}

\section{Results}

Hypocenter Locations of the pre-Methoni and post-Methoni seismicity

232 Post-Methoni seismic activity is observed along the strike of the subduction zone (WNW-ESE) for

233 over $300 \mathrm{~km}$, from west of the Peloponnesus up to the south-western coast of Crete (Fig.3a). Most of

234 the seismicity is localized within a $10-30 \mathrm{~km}$ wide band beneath the Matapan Trough (MT) region. A

235 similar pattern was observed for the pre-Methoni period (Fig.3b). To the SE, along the deepest part of 236 the MT, earthquakes are distributed along both sides of the depression, with most events remaining 237 along its southern border. Towards Crete, seismicity is more scattered and the seismic rate is 238 comparable during the time of the two experiments.
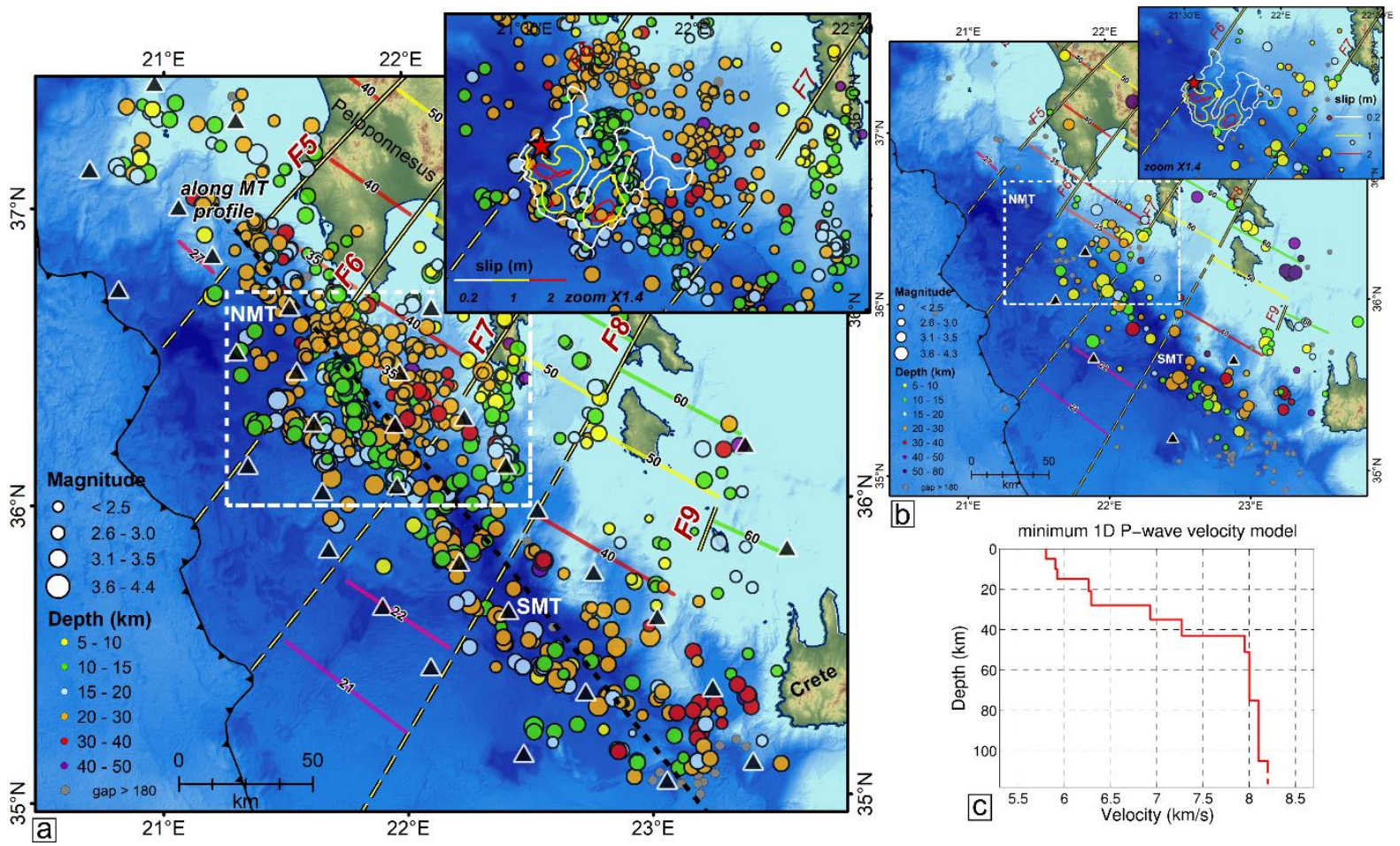

240 Fig. 3. Map view of seismic activity beneath the offshore forearc domain of the (a) post and (b) pre-

241 Methoni experiments. Earthquakes of both periods are located using the plotted (c) minimum 1D P- 
wave velocity model determined by the present study. The epicenters are marked by circles, scaled

243 by their magnitude with events of azimuthal gap $<180^{\circ}$ colour-coded according to their focal depth

244 (gray ones have gap $>180^{\circ}$ ). The black dashed line drawn in the along-Matapan NW-SE direction in 245 panel (a) is used for the cross-section of Fig.A.1c. Inset maps: a zoomed view of panel F6F7, marked

246 by a white dashed rectangle in the main figures. Methoni coseismic slip is superposed while the star

247 denotes the epicenter of Methoni earthquake.

Post-Methoni seismic activity is more sustained along the panel F6F7, especially in its northwestern part (Fig.3a Inset). This contrasts with the pre-Methoni period when the Methoni coseismic slip area is nearly devoid of seismic activity (Fig.3b). The quiescent area includes the part of fault F6 where the mainshock initiated. Instead, the fault is very active downdip of the rupture extent, with a large number of earthquakes located along this structure. To the SW, a stripe of earthquakes striking WNW is located along the updip border of the rupture (Fig.3a).

Integration of the existing information on the plate interface depth and geometry enables the characterization of the hypocenters with respect to the two plates. We hereafter focus on panel F6F7 which hosted the Methoni earthquake. RF imaging provides constraints on the depth of the slab Moho downdip the rupture (Sachpazi et al., 2016 a,b). However, the depth of the plate interface further updip, hence along the coseismic domain is unknown. Hypocentral locations of subduction thrust earthquakes such as the Methoni event may potentially provide a first order estimate of the depth of the interplate boundary. However in the present case reported hypocenters, are based mainly on distant observations, and spread over more than $40 \mathrm{~km}$ both horizontally and in depth (Fig.2a Inset map). Sachpazi et al. (2016b), used phase-arrival data from the TWR land array, in addition to permanent stations, to determine hypocentral locations for the Methoni mainshock and its largest aftershocks by a simple 3-layer model with $\mathrm{Vp} / \mathrm{Vs}=1.75$. This resulted in a focal depth of $15 \mathrm{~km}$ for the mainshock, which the authors proposed as the plate interface depth. We re-examine the mainshock's hypocentral location, using the 1D P-wave velocity model obtained from this study. For the construction of the minimum 1D Vp model, besides OBS, we have also employed data from land-based stations (see Fig. 
269 B.1 in the supplementary material). Many of these have available data for the 2008 mainshock. The

270 main reason the focal depth for this earthquake is so unstable is due to the fact that there were no local

271 stations (OBS) at that time and there are significant azimuthal gaps. Thus, the trade-off between the

272 hypocentral and velocity model parameters results in unrealistically small RMS and uncertainty

273 estimates. In this study, we investigate the resulting range of focal depths for the mainshock by

274 changing the only parameters for which we have control, i.e. the velocity model and distance

275 weighting. In contrast to the seismicity of the post-Methoni experiment which was located using only

276 P-wave data and the minimum 1-D Vp model, in the case of the mainshock we also employ a constant

$277 \mathrm{Vp} / \mathrm{Vs}$ ratio, in order to take advantage of the available S-wave arrivals, and examine how different

$278 \mathrm{Vp} / \mathrm{Vs}$ values affect the RMS error and the resulting depth. We take all these parameters into account

279 to estimate a possible range for the focal depth of the mainshock. The resulting focal depth for the

280 mainshock ranges from $26.5 \mathrm{~km}$ to31.0 km, depending mainly on the selection of $\mathrm{Vp} / \mathrm{Vs}$ and the

281 incorporation of distant stations. We obtained lower RMS values $(0.27-0.28 \mathrm{~s})$ when limiting the

282 distance weighting to $50-200 \mathrm{~km}$. $\mathrm{Vp} / \mathrm{Vs}=1.83$ yields the smallest $\mathrm{RMS}=0.27 \mathrm{~s}$ which is also the value

283 supported by the Chatelain (1978) diagram for the available 2008-2009 OBS data, resulting in a focal

284 depth of $27 \mathrm{~km}$ for the mainshock. Additional tests of single-event location of the 2008 mainshock

285 with VELEST, with or without taking into account S-wave arrivals, resulted in greater focal depths

$286(30.5-32.0 \mathrm{~km})$, but the RMS was also higher $(0.42-0.45 \mathrm{~s})$. The epicentral location of the mainshock

287 does not vary significantly in the various tests. It is clear that these various tests do not provide a way

288 to control quantitatively the hypocenter, however, the 1D P-wave velocity model of this study is an

289 improvement over the crude 3-layer model that was used before (model Y in Fig. B.3a in the

290 supplementary material). Note that all the starting models (including Model Y) follow a roughly

291 similar profile with depth (Fig. B.3a). However, starting model Y yielded the worst results (Fig. B.2,

292 test Y2DS3). Following the above mentioned estimates we adopt a mean focal depth of $23 \mathrm{~km}$ for the

2932008 mainshock with an uncertainty of $\pm 5 \mathrm{~km}$.

294 Spatiotemporal analysis of post-Methoni seismic activity outlines 7 groups within panel F6F7 that

295 characterize different parts of the activated region (Fig.4a, b). The distribution of the hypocenters

296 jointly with their evolution in time and the part of the subduction system where these occur are 
analytically discussed in the Appendix A. The constrained focal mechanisms (Fig.4c) and their P, T

298 principal axes (Figure S1) also allow for several interesting observations and are hereafter jointly 299 discussed.

\section{Discussion}

In this work, offshore seismicity has been constrained both horizontally and in depth by our dense local array of OBS stations, during a period between 9 and 21 months after the Methoni mainshock.

Despite its moderate magnitude in comparison to megathrust earthquakes in other subduction zones, the Methoni earthquake, is the largest interplate earthquake within the $400 \mathrm{~km}$ long western Hellenic subduction zone for over a half-century and was followed by post-seismic slip, as large as the coseismic slip, during the 3 year period after the mainshock. According to geodetic data modeling by Howell et al. (2017a), the afterslip area was twelve times larger than the coseismic patch, over a 100km-wide segment spanning through the two panels F5-F6 and F6-F7, centered on the Methoni rupture (Fig.1b). The poorly constrained geodetic updip and downdip limits have been chosen to correspond to

311 the forearc backstop trenchward edge and the $35 \mathrm{~km}$ depth respectively. The latter is roughly located 312 below the Messenia and Mani capes.

313 Here we investigate the geometry and character of the post-Methoni seismicity within panel F6F7

314 (Fig.4a, b). We discuss it with respect to the shape and extension of the rupture area as well as the widely distributed post seismic deformation.

316 Two clusters (\#6 in cyan and \#7 in black) are located at depths above the updip and downdip edges 317 of the rupture area, respectively (Fig.4b). Hypocenters extend through a $10 \mathrm{~km}$ thick layer above the 318 interplate fault with only few events reaching shallower depths. These events have not been observed 319 by our pre-Methoni offshore-onshore deployment, which is also the case for the other clusters 320 discussed hereafter.

There is a complete lack of interplate activity between cluster \#6 and \#7 over a downdip width of about $30 \mathrm{~km}$ corresponding to the Methoni rupture area (Fig.4b and Fig.A.1b Profiles 1,2). It has been observed for many of the $M>8$ earthquakes such as Sumatra (Hsu et al., 2006), Chile (Hayes et al.,

324 2014b; Li et al., 2016), and Tohoku (e.g Asano et al., 2011) that large co-seismic slip areas tend to 
have little interplate seismicity after the mainshock rupture. The distribution of hypocenters, 9-21 months after the moderate $\mathrm{Mw}=6.8$ Methoni earthquake shows a similar feature. In addition, we observe that the surrounding deep upper plate volume, right above the plate interface is similarly quiet (Fig.4b).

There is a strong concentration of hypocenters along the slab fault F6 (Fig.4a, clusters \#1 (red) and \#2 (green). Coseismic slip occurring on the megathrust fault plane which is here laterally bordered by a vertical fault zone located in the upward extent of the intraslab F6 fault, may induce earthquake swarms by micro-faulting. The present study area is located at shallower depths than the Moho of the overriding plate which is identified at $\sim 30 \mathrm{~km}$ depth beneath Messiniakos gulf (Sachpazi et al., 2016a).

334 The overlying portion of the Aegean plate is thus largely crustal. The fact that the clusters \#1 (red) and \#2 (green) occur in the upper-plate crust (Fig.4b) within a vertical plane above the intra-slab fault F6, may highlight a process that triggers activity through fluid migration in a pre-stressed region above. Though, this activity is located downdip and not over the co-seismic area along the fault F6 due to post-seismic stress relaxation (see Fig. 5b Lin and Stein, 2004) and/or due to lateral variation of fluids in the crustal material above the fault region. In fact, many causes might contribute to the observed spatio-temporal evolution.

341 The slab faults have already been shown to correlate with clustered seismicity, but this occurred at the 60-80 km slab depth within the subducting crust further downdip, beneath NE Peloponnesus and have been proposed to channel slab dehydrating fluids (Sachpazi et al., 2016a). Recent results,

344 focusing on Greece but extended also to other subduction zones, proposed that fluids may migrate 345 along the slab further updip and upwards, towards the overriding crust to trigger upper plate 346 seismicity (<40km depth) (Halpaap et al., 2019). Our spatio-temporal analysis has shown that the 347 shallower cluster along the fault F6 (cluster \#1, red) precedes the deeper one (cluster \#2, green) 348 (Fig.A.1a), thus the fore-mentioned mechanism looks unlikely for our observations. Yet, it is possible that dehydration occurs locally at depth and that the deeper cluster is diagnostic of the upwards channelling of fluids. afterslip (Howell et al., 2017a) (Fig.1b). This is where seismicity downdip of the coseismic rupture 
353 (group \#7, cluster in black) is located right above and on top of the plate interface (Fig.4b). This is

354 still located in the crust-to crust contact and the interplate is not yet under the mantle of the upper

355 plate. So we can think of these aftershocks as essentially being driven by brittle creep as proposed by

356 Perfettini \& Avouac (2004) for deep afterslip. Slow slip in the downdip part of the slab fault F6 may

357 be an alternative mechanism to explain the earthquake clustering and induced deformation within the

358 upper plate (clusters \#1, \#2). This would be due to the differential motion between the slab panels

359 along this fault.

3605.1 Focal mechanisms and the nature of seismic deformation with respect to the plate interface

361 Cluster \#6 (cyan), located updip of the rupture area and just above the interplate boundary, is 362 related with reverse and strike slip events (20-23km depth) with a P axis striking NE-SW (Fig. 4c and

363 Fig. S1), consistent with the mainshock and major aftershocks (Fig.2a). Cluster \#5 orange, located 364 instead beneath the rupture area and within the subducting crust (Fig.4b) contains normal-faulting 365 events with a T-axis trending between N-S and NE-SW (26-30km depth) (Fig. 4c and Figure S1). This

366 type of faulting is also observed in events located at the same depths in the nearby region of panel

367 F7F8 with a T-axis trending roughly WE (Fig.4c). 

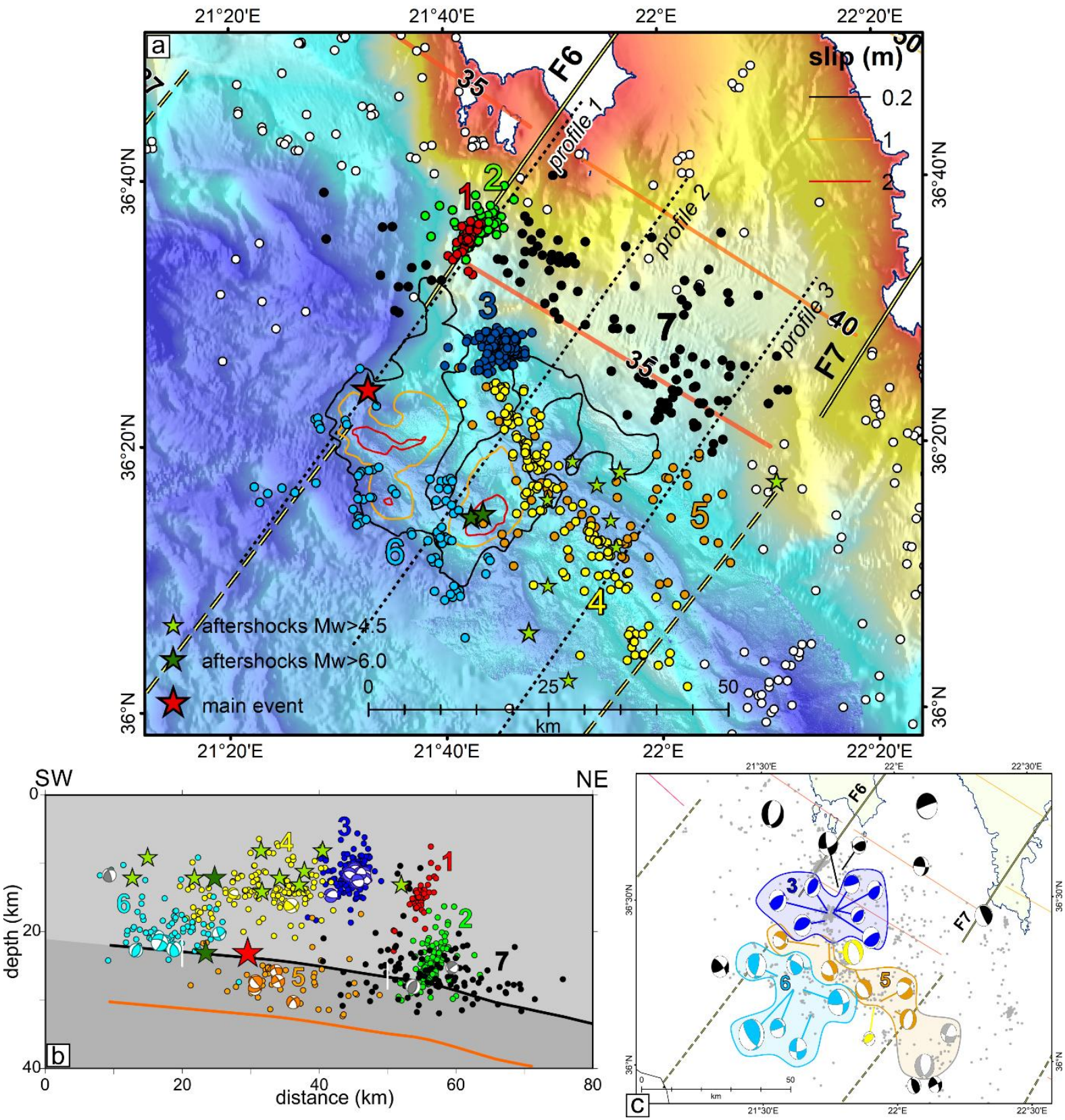

Fig. 4. (a) Seismicity of panel F6F7 with relocated epicenters using the double-difference method.

370 Colors and numerical labels correspond to the 7 spatial groups discussed in the main text and

371 Appendix A. Methoni coseismic slip is superposed. Profiles 1-3 (black dotted lines), drawn in a

$372 \mathrm{~N} 35^{\circ} \mathrm{E}$ direction are used for the cross-sections of figure A.1.b. (b) Cross-section of the relocated

373 seismicity in a $\mathrm{N} 35^{\circ} \mathrm{E}$ direction covering the whole width of panel F6F7. Beachballs present the far-

374 hemisphere projections of selected focal mechanisms, with their compressive quadrants following the

375 same colour-coding as the hypocenters of the respective 7 spatial groups except for those with gray colour which do not belong to them. Hypocenters locations of the Methoni mainshock (red star) and 
stronger aftershocks (green stars) of the first period (Fig.2b) are from the present study. Areas with

378 light and dark gray shading represent the upper and lower plate, respectively. The bold black line shows the plate interface with the two white vertical ticks denoting the 30-km-long downdip mainshock rupture width along the western part of the panel. The bold orange line is the slab Moho assuming an 8km thick oceanic crust (Gesret et al., 2010) (c) Focal mechanisms for events within panel F6F7 and its vicinity. Beachballs with black and gray compressive quadrants correspond to events at depths related to the upper and lower plate, respectively.

In the offshore domain between the southwest Peloponnesus and Crete, focal mechanisms of the most significant earthquakes in the last 40 years show that the regional stress field corresponds to two types of faulting. The first, reverse and low-angle thrust faulting with a NE horizontal compressive axis, has been considered to reflect the SW overriding of the Aegean domain over the Ionian oceanic crust causing also the large inter-plate subduction earthquakes (Shaw and Jackson, 2010; Benetatos et al., 2004; Kapetanidis and Kassaras, 2019). The second, reverse faulting within the lower plate with a trench parallel compressive axis is proposed to correspond to along-arc shortening of the subducted slab (Shaw and Jackson, 2010).

393 However, at the NW part of the subduction, in the Ionian Islands, small normal-fault earthquakes with a W-E trending T-axis have been resolved at shallow depths within the slab crust, by an early

395 OBS and land-based network (Sachpazi et al., 2000). These events found trenchward of a change in 396 the dip of the interplate boundary (Hirn et al., 1996), were interpreted as reflecting the bending of the

397 lower plate. These types of events have also been found along the Japan trench and similarly attributed 398 to bending-related faulting of the subducting crust (Gamage et al., 2009). In the Ionian islands, in 399 addition to the lower plate extensional earthquakes, reverse-faulting events have been located in the 400 upper plate above the interplate boundary, exhibiting a NE striking P-axis. The contrasting focal 401 mechanisms on either side of the seismically imaged refelctor -at $15 \mathrm{~km}$ depth- were evidence it was

402 the plate interface. We suggested that lower plate bending was due to the load of the southwestwards 403 overriding upper plate which thickens landwards. 
Our findings in the present study of the southwestern part of the subduction zone are consistent with these characteristics of background seismicity of the Ionian Islands. The normal fault earthquakes are in the lower plate crust and trenchwards of the thickened Hellenic continental margin and may mark the lower plate bending to underthrust the southwestwards advancing upper plate (Le Pichon et al., 2019). The plate interface may be thus defined as the boundary (at the $24-25 \mathrm{~km}$ depth range) between the two groups of different focal mechanisms, with those around 20-23 km depth being at the base of the overriding upper plate, consistently with the proposed Methoni mainshock's hypocenter at $23 \mathrm{~km}$ depth.

\subsection{Seismic activity within the shallow upper plate}

The third group (cluster \#3, blue) in the shallower part of the upper plate is located $10 \mathrm{~km}$ above

414 the plate interface and above the downdip coseismic border region (Fig.4b). It displays reverse 415 faulting events with an along-arc P-axis (Fig.4c and Figure S1) that differs significantly from the regional NE striking horizontal compressive axis. It is possible that this seismic swarm in the hanging wall, which occurred 13 months after the mainshock, is associated with Coulomb stress transfer above the lateral variation of rupture imposed on an obliquely orientated structure (Vallage et al., 2014). relation has already been noted during the pre-Methoni period, in the wider offshore forearc, though MT associated activity was not continuing into panel F6F7 (Fig.3b). During the post-Methoni period, MT is seismically active at the $10-15 \mathrm{~km}$ depths range into panel F6F7. This suggests the presence of deep active faults controlling its morphological expression at the sea bottom within the outer forearc crust, which have been seismically activated in the post-Methoni period (Fig.3a). The focal mechanisms we could constrain for two events at $15 \mathrm{~km}$ depth beneath MT (panel F7F8) display reverse and strike slip faulting respectively with a NE trending P-axis (Fig.4c and Figure S1). The extensional process that was suggested for the formation of this deep outer forearc domain (Lallemant et al., 1994) is possibly currently replaced by oblique compression. This might result from the combined effect of the ongoing collision between the backstop and the Lybian margin south of Crete, as suggested by Mascle and Chaumillon (1998), and from the predicted $\sim 2 \mathrm{~cm} / \mathrm{yr}$ of dextral motion at the trenchward backstop's edge as suggested by Chamot-Rooke et al. (2005). 
We document a seismic activation of the upper plate which appears to accommodate deformation 434 on small faults with different orientations around and above the area of mainshock slip. We attribute this activation to a part of the post-seismic deformation which spreads induced elastic deformation into the forearc hanging wall of the interplate fault. Howell et al., 2017a model the $20 \mathrm{~mm}$ post seismic displacement as mainly related to widespread aseismic slip of the plate interface. It is beyond the scope of this paper to interpret GPS data but we note a change in the slope of geodetic offset (see time series of stations METH and KERY at Fig.4b of Howell et al., 2017a and inset panel in Fig.2b) at the end of 2008. Most of the $\sim 15 \mathrm{~mm}$ post seismic displacement occurs before the end of 2008 and the remaining $\sim 5 \mathrm{~mm}$ continue up to the end of 2010 . The onset of slow deformation coincides in time with the initiation of the smaller clustered activity during our post-Methoni experiment (Fig.2b). The earlier large aftershocks which also occurred in the shallow upper plate took place during the first period of faster rate deformation (Fig.2b). Their focal mechanisms, strike slip as well as reverse faulting, are compatible with upper plate deformation, also shown in the kinematics of the co-seismic slip, which is driven by the SW movement of the overriding plate.

We also resolve the eastern part of panel F6F7 which did not slip coseismically, to be devoid of interplate activity in the $30 \mathrm{~km}$ downdip range (Fig.A.1b Profile 3). The $\mathrm{Mw}=6.8$ main shock was followed 2 hours later by the $\mathrm{Mw}=6.5$ interplate aftershock at the southeastern border of the Methoni asperity which may have continued the rupture in some extent to the SE, towards slab fault F7 (Sachpazi et al., 2016b). Unfortunately available data are insufficient to model its co-seismic slip; hence its along-dip extent is unknown. Thus, we cannot exclude the possibility that a part of the silent plate interface of the eastern panel has experienced aseismic slip as proposed by Howell et al., 2017a. seismically quiet in comparison to the eastern one (Fig.3b), which may also be observed in the several years back, -though less well resolved- NOA seismicity (Fig.ureS2). NOA epicentral locations following our post-Methoni experiment (2010-2019) show a progressive decrease in seismic activityalso along the wider forearc- and approach to the pre-Methoni state (Fig.S3 panel F6F7). Over the 
between the plates (Sachpazi et al., 2016b). The persistence of MT related seismic activity, -outside

461 panel F6F7- during our short-term pre- and post-Methoni experiments suggests a difference in the

462 seismic behavior along the forearc. It is possible that the same processes we proposed to drive postseismic deformation of panel F6F7, such as dehydration-embrittlement and/or aseismic slip, are behind the continuous MT related seismic activity. Clarifying the processes at work will require seabottom geodetic and seismic monitoring.

We have shown that the clustered post-Methoni seismic activity within the outer forearc crust on the one hand and the localized slip during the Methoni earthquake along the plate interface on the other hand, accommodate complementary patterns of the seismic deformation, over the megathrust boundary. Oblique convergence structures were up to now considered to be restrained at the trenchward backstop's edge (Chamot Rooke et al., 2005), and the Methoni sequence documents a potentially active oblique deformation up to the Matapan Trough. Our findings, on the Methoni sequence document in detail the characteristics of this part of the SW Hellenic subduction zone with a highly deformable Aegean plate overriding a segmented lower plate.

\section{Conclusions}

The results of our long-term aftershocks study of the Methoni Mw 6.8 interplate event, acquired from recordings of both OBS and land stations, provide insights into the SW Hellenic megathrust domain where large events are uncommon, though a large historical tsunamogenic event has occurred in the past (Papazachos and Papazachou, 2003; Stiros and Papageorgiou, 2001). We establish spatial correlation between the regional seismicity pattern and the Matapan Trough, a major -250-km-long forearc basin within our study area, already identified by our previous studies with less dense datasets (Sachpazi et al., 2016b). We discuss spatio-temporal variations of the long-term aftershocks activity, which clustered over the Methoni co-seismic and post-seismic slip area thanks to depth constraints and focal mechanisms.

We showcase clear evidences of post-Methoni crustal seismicity occurring on mega-thrust asperities and forearc crust's faults, as well as the impact of the slab segmentation (slab fault F6) in

487 the spatial distribution. These features did not show up before the 2008 Methoni earthquake as 
documented by comparison with pre-Methoni seismic studies (Sachpazi et al., 2016b). Though the

489 largest crustal aftershocks account for only a small fraction of the moment release and post-seismic

490 slip documented by GPS data (Howell et al., 2017a), our results indicate that the observed post-

491 Methoni microseismic activity is consistent with complementary post-seismic slow deformation

492 which spreads into the forearc region rather than on the plate interface.

493

494

495

496

497

498

499

500

501 anonymous reviewers for their constructive evaluation.

502

503

\section{References}

504

Asano, Y., Saito, T., Ito, Y., Shiomi, K., Hirose, H., Matsumoto, T., Aoi, S., Hori, S., Sekiguchi, S., 2011. Spatial distribution and focal mechanisms of aftershocks of the 2011 off the Pacific coast of Tohoku earthquake. Earth Planet. and Space 63, 669-673. https://doi .org /10.5047 /eps .2011.06

507.016

508 Baker, C., Hatzfeld, D., Lyon-Caen, H., Papadimitriou, E., Rigo, A., 1997. Earthquake mechanisms 509 of the Adriatic Sea and Western Greece: geodynamic implications for the oceanic subduction510 continental collision transition. Geophys. J. Int. 131, 559-594.

511 Benetatos, C., Kiratzi, A., Papazachos, C., Karakaisis, G., 2004. Focal mechanisms of shallow and

512 intermediate depth earthquakes along the Hellenic Arc. C. Journal of Geodynamics, 37, 253-296.

513 Brosolo, L., Mascle, J., Loubtrieu, B., 2012. Morpho-Bathymetry of the Mediterranean Sea, Map 514 1/4.000.000, 1st ed., Comm. for the Geol. Map of the World (CGMW) and UNESCO, Paris. 
515 Cattania, C., Hainzl, S., Wang, L., Enescu, B., Roth, F., 2015. Aftershock triggering by postseismic

516 stresses: A study based on Coulomb rate-and-state models. J. Geophys. Res., Solid Earth, 120, 2388-

517 2407. https://doi:10.1002/2014JB011500.

518 Chamot Rooke, N., Rabaute, A., Kreemer, C., 2005. Western Mediterranean Ridge mud belt 519 correlates with active shear strain at the prism-backstop geological contact. Geology 33(11), 861-864.

520 https://doi: 10.1130/G21469.

521 Chatelain, J.L., 1978. Etude fine de la sismicite en zone de collision continentale au moyen d'un

522 r'eseau de stations portables: la regionHindu-Kush Pamir, These de 3eme cycle, Universite de 523 Grenoble, 219 pp.

524 Chaumillon, E., Mascle, J., Hoffmann, H.J., 1996. Deformation of the western Mediterranean Ridge: 525 Importance of Messinian evaporitic formations. Tectonophysics 263, 163-190.

526 England, P., Houseman, G., Nocquet, J.M. 2016. Constraints from GPS measurements on the 527 dynamics

528 of deformation in Anatolia and the Aegean. J. Geophys. Res.: Solid Earth, 121: 8888-8916, 529 doi:10.1002/2016JB013382.

530 Gamage, S.S.N., Umino, N., Hasegawa, A., Kirby, S.H., 2009. Offshore double-planed shallow 531 seismic zone in the NE Japan forearc region revealed by sP depth phases recorded by regional 532 networks. Geophys. J. Int. 178, 195-214.

533 Gesret, A., Laigle, M., Diaz, J., Sachpazi, M., Hirn, A., 2010. The oceanic nature of the African slab 534 subducted under Peloponnesus: Thin-layer resolution from multiscale analysis of teleseismic P to S 535 converted waves. Geophys. J. Int. 183, 833-849. https://doi:10.1111/j.1365-246X.2010.04738.x.

536 Halpaap, F., Rondenay, S. Perrin, A., Goes, S., Ottemoller, L., Austrheim, H., Shaw, R., Eeken T., 537 2019. Earthquakes track subduction fluids from slab source to mantle wedge sink. Sci. Adv. 5(4), 538 eaav7369.

539 Hayes, G.P., Furlong, K.P., Benz, H.M., Herman, M.W., 2014a. Triggered aseismic slip adjacent to 540 the 6 February 2013 MW 8.0 Santa Cruz Islands megathrust earthquake. Earth Planet. Sci. Lett. 388, $541 \quad$ 265-272. https://doi .org /10.1016/j.epsl.2013.11 .010 . 
542 Hayes, G.P., Herman, M.W., Barnhart, W.D., Furlong, K.P., Riquelme, S., Benz, H.M., Bergman, E.,

543 Barrientos, S., Earle, P.S., Samsonov, S., 2014b. Continuing megathrust earthquake potential in Chile

544 after the 2014 Iquique earthquake. Nature 512, 295-298. https:// doi .org /10 .1038/nature13677.

545 Hirn, A., Sachpazi, M., Siliqi, R., Mc Bride, S., Marnelis, F. and the STREAMERS/PROFILES

546 group, 1996. A traverse front with coincident normal incidence and wide angle seismic.

547 Tectonophysics 267, 57-71.

548 Howell, A., Palamartchouk, K., Papanikolaou, X., Paradissis, D., Raptakis, C., Copley, A., England,

549 P., Jackson, J., 2017a. The 2008 Methoni earthquake sequence: the relationship between the

550 earthquake cycle on the subduction interface and coastal uplift in SW Greece. Geophys. J. Int. 208, $551 \quad 1592-1610$.

552 Hsu, Y.J., Simons, M., Avouac, J.P., Galetzka, J., Sieh, K., Chlieh, M., Natawidjaja, D., 553 Prawirodirdjo,

554 L., Bock, Y., 2006. Frictional afterslip following the 2005 Nias-Simeulue earthquake, Sumatra.

555 Science 312, 1921-1926. https:// doi .org /10.1126/science .1126960.

556 Huchon, P., Lyberis, N., Angelier, J., Le Pichon, X., Renard, V., 1982. Tectonics of the Hellenic 557 trench: a synthesis of Seabeam and submersible observations. Tectonophysics 86, 69-112.

558 Hussni, S., Becel, A., Schenini, L., Laigle, M., Dessa, J.X., Galve, A., Vitard, A., SISMED Scientific 559 Team. 2017. Pre-Stack depth Migration imaging of the Hellenic Subduction Zone. POSTER 560 SESSION AGU FALL MEETING.

561 Jongsma, D., 1977. Bathymetry and shallow structure of the Pliny and Strabo Trenches south of the

562 Hellenic Arc. Geol. Soc. Am. Bull. 88, 797-805.

563 Jackson, J., McKenzie, D., 1988. The relationship between plate motions and seismic moment

564 tensors, and the rates of active deformation in the Mediterranean and Middle East. Geophys. J. R.

565 Astr. Soc. 93, 45-73.

566 Jackson, J., McKenzie, D., 1988. Rates of active deformation in the Aegean Sea and surrounding 567 regions, Basin Res. 1, 121-128. 

strain rate field within the boundary zones of the Eurasian, African, and Arabian plates, J. Geophys. Res. 105, 23,353-23,370. https://doi:10.1029/2000JB900238.

Kapetanidis, V., Kassaras, I., 2019. Contemporary crustal stress of the Greek region deduced from earthquake focal mechanisms. J. of Geodynamics 123, 55-82.

573 Kissling, E., 1995. Program VELEST user's guide - short introduction, Institute of Geophysics, ETH 574 Zurich.

575 Kissling, E., Ellsworth, W.L., Eberhart-Phillips, D., Kradolfer, U., 1994. Initial reference models in 576 local earthquake tomography. J. Geophys. Res. 99, 19635-19646. https://doi: 10.1029/93JB03138.

577 Laigle, M., Sachpazi, M. Hirn, A., 2004. Variation of seismic coupling with slab detachment - upper 578 plate structure along western Hellenic subduction. Tectonophysics 391, 85-95. Lallemant, S., Truffert, C., Jolivet, L., Henry, P., Chamot-Rooke, N., de Voogd, B., 1994. Spatial 580 transition from compression to extension in the Western Mediterranean Ridge accretionary complex.

581 Tectonophysics 234, 33-52.

582 Lee, W.H.K.,Valdes, C.M., 1989. User manual for HYPO71PC, in Lee, W.H.K., ed., Toolkit for 583 seismic data acquisition, processing and analysis: El Cerrito, Calif. Seismological Society of America, 584 International Association of Seismology and Physics of the Earth's Interior Software Library, v. 1, p. 203-236.

586 Li, L., Lay, T., Cheung, K.F., Ye, L., 2016. Joint modeling of teleseismic and tsunami wave 587 observations to constrain the 16 September 2015 Illapel, Chile, $M W 8.3$ earthquake rupture process.

588 Geophys. Res. Lett. v. 43, p. 4303-4312. https:// doi .org /10.1002 /2016GL068674.

589 Lin, J., Stein, R. S., 2004. Stress triggering in thrust and subduction earthquakes and stress interaction 590 between the southern San Andreas and nearby thrust and strike- slip faults. J. Geophys. Res. 109, $591 \quad$ B02303. https://doi:10.1029/2003JB002607.

592 Le Pichon, X., Angelier, J., Sibuet, J.-C., 1982. Plate boundaries and extensional tectonics.

593 Tectonophysics 81, 239-256.

594 Le Pichon, X., Lallemant, S, 2002. The Mediterranean Ridge backstop and the Hellenic nappes. 595 Marine geology 186,111-125. 
596 Le Pichon, X., Sengor, C.A.M., Imren, C., 2019. A new approach to the opening of the Eastern

597 Mediterranean Sea and the origin of the Hellenic Subduction Zone. Part 2 The Hellenic Subduction.

598 Can. J. Earth Sci. 56, 1144-1162.

599 Mascle, J. Chaumillon, E., 1998. An overview of Mediterranean Ridge collisional accretionary

600 complex as deduced from multichannel seismic data. Geo-Mar. Lett. 18, 81-89.

601 Meier, T., Rische, M., Endrun, B., Vafidis, A. Harjes, H. P., 2004a. Seismicity of the Hellenic

602 subduction zone in the area of western and central Crete observed by temporary local seismic

603 networks, Tectonophysics 383(3), 149-169.

604 Nocquet, J. M., 2012 Present Day kinematics of the Mediterranean: A comprehensive overview of

605 GPS results. Tectonophysics https:// doi .org /10.1016/j.tecto.2012.03.037.

606 North, R.G., 1974. Seismic slip rates in the Mediterranean and Middle East. Nature 252, 560-563.

607 Ozawa, S., Nishimura, T., Munekane, H., Suito, H., Kobayashi, T., Tobita, M., Imakiire, T., 2012.

608 Preceding, coseismic, and postseismic slips of the 2011 Tohoku earthquake, Japan: J. Geophys, Res.

609117 B07404. https:// doi .org /10.1029/2011JB009120.

610 Papazachos, B. C., Papazachou, K., 2003. The Earthquakes of Greece, 286 pp., Ziti Publ.,

611 Thessaloniki.

612 Perfettini, H., Avouac, J.-P., 2004. Postseismic relaxation driven by brittle creep: A possible

613 mechanism to reconcile geodetic measurements and the decay rate of aftershocks, application to the

614 Chi-Chi earthquake, Taiwan. J. Geophys. Res. 109, B02304. https:// doi:10.1029/2003JB002488.

615 Reilinger, R., McClusky, S., Paradissis, D., Ergintav, S., Vernant, P., 2010. Geodetic constraints on the

616 tectonic evolution of the Aegean region and strain accumulation along the Hellenic subduction zone.

617 Tectonophysics 488, 22-30.

618 Reston, T. J., von Huene, R., Dickmann, T., Klaeschen, D., Kopp, H., 2002b. Frontal accretion along

619 the western Mediterranean Ridge: the effect of Messinian evaporites on wedge mechanics and 620 structural style. Marine geology 186(1), 59-82. 
621 Roumelioti, Z., Benetatos, C., Kiratzi, A., 2009. The 14 February 2008 earthquake (M6.7) sequence

622 offshore south Peloponnese (Greece): Source models of the three strongest events. Tectonophysics 623 471, 272-284. https:// doi:10.1016/j.tecto.2009.02.028.

624 Sachpazi, M., Hirn, A., Clément, C., Haslinger, F., Laigle, M., Kissling, E., Charvis, P., Hello, Y., 625 Lépine, J.C., Sapin, M., Ansorge, J. 2000. Western Hellenic subduction and Cephalonia transform: 626 local earthquakes and plate transport and strain. Tectonophysics 319, 301-319.

627 Sachpazi, M., Laigle, M., Charalampakis, M., Diaz, J., Kissling, E., Gesret, A., Becel, A., Flueh, E., 628 Miles, P., Hirn, A., 2016a. Segmented Hellenic slab rollback driving Aegean deformation and 629 seismicity. Geophys. Res. Lett. 43, 651-658. https://doi:10.1002/2015GL066818.

630 Sachpazi M., Laigle, M., Charalampakis, M., Sakellariou, D., Flueh, E., Sokos, E., Daskalaki, E., 631 Galvé, A., Petrou, P., Hirn, A., 2016b. Slab segmentation controls the interplate slip motion in the SW 632 Hellenic subduction: New insight from the $2008 \mathrm{Mw} 6.8$ Methoni interplate earthquake. Geophys. 633 Res. Lett. 43, 9619-9626.

634 Shaw, B. et al., 2008. Eastern Mediterranean tectonics and tsunami hazard inferred from the AD 365 635 earthquake, Nat. Geosci. 1(4), 268-276.

636 Shaw, B., Jackson, J., 2010. Earthquake mechanisms and active tectonics of the Hellenic subduction 637 zone. Geophys. J. Int. 181, 966-984. https:// doi:10.1111/j.1365-246X.2010.04551.x.

638 Stiros, S.C., Papageorgiou, S., 2001. Seismicity of Western Crete and the destruction of the town of 639 Kisamos at AD 365: archaeological evidence. J. Seismol. 5, 381-397.

640 Vallage, A., Deves, M. H., Klinger, Y., King, G. C. P., Ruppert, N. A., 2014. Localized slip and 641 distributed deformation in oblique settings: the example of the Denali fault system, Alaska. Geophys.

642 J. Int. https:// doi: 10.1093/gji/ggu100.

643 Vernant, P., Reilinger, R., Mc Clusky, S., 2014. Geodetic evidence for low coupling on the Hellenic 644 subduction plate interface. Earth Planet. Sci. Lett 385, 122-129. http://dx.doi.org/10.1016/ $645 \quad$ j.epsl.2013.10.018.

646 Vitard, C., Charvis P., Laigle M., Sachpazi M., Galve A., Schenini L., Dannowski A., Spyridon B., 647 2015. Structural analysis of the southwestern segment of the Hellenic subduction zone by joint 648 analysis of seismic reflection and refraction. Poster, Fall Meeting, AGU, San Francisco, Calif. 
649 Yagi, Y., Kikuchi, M., Nishimura, T., 2003. Co-seismic slip, post-seismic slip, and largest aftershock

650 associated with the 1994 Sanriku-haruka-oki, Japan, earthquake. Geophys. Res. Lett. 30, 2177. https:// doi:10.1029/2003GL018189.

652

\section{APPENDIX A}

Spatiotemporal analysis of the 2008-2009 Methoni seismicity

To enable the spatiotemporal analysis of the Methoni earthquake sequence during the study period, we applied a spatial grouping methodology similar to the one followed for the relocation procedure to the final catalogue which is fully described in the Supplementary Material. Particular focus was placed in the clustered seismicity that has occurred within panel F6F7 and especially on slab fault F6, while the rest of activity in the other panels or further onshore is considered here as a "background seismicity". An inter-event distance matrix was constructed for the focused seismicity and Ward's (1963) linkage was applied to create hierarchical clustering. By selecting proper thresholds, the seismicity was initially divided in several spatial groups, which were then adjusted, merged and reduced to a selection of 7 groups that characterize different parts of the activated region within panel F6F7 (Fig.4a). Post-Methoni activity at the beginning of the experiment (mid-October 2008), 9 months after the mainshock (M) presented a relatively steady background rate of about 2-3 events per day (Fig.A.1a).

\section{Group \#1 red (M+10 months)}

On 14 December, a sudden increase of activity was identified as group \#1 (red). Epicentres were aligned along the trace of slab fault F6 beyond the downdip rupture area (Fig.4a), but at much shallower depths of 12-17 km, hence in the upper plate (Fig.A.1b Profile 1). This spatiotemporal cluster began with smaller events was then followed by a larger one $\left(\mathrm{M}_{\mathrm{L}}=4.2\right)$ and continued for 11 672 days.

On 15 January 2009, a different cluster (\#2; green) was activated on slab fault F6 (Fig.4a), mostly in the overriding plate at depths of 20-28km (Fig. A.1b Profile 1). This cluster evolved into a series of small bursts including mainly a few $\mathrm{M}_{\mathrm{L}}>3.0$ events, with the larger being an $\mathrm{M}_{\mathrm{L}}=3.5$ event (Fig. A.1a). 
677 Most of its activity was over by mid-February 2009. Although cluster \#2 is located close to \#1, both

678 being downdip of the northwestern coseismic slip patch extent (Fig.4a), they are well-separated in 679 both space and time and have occurred at distinctly different depths. Both are located in the upper 680 plate while the second one extends downward to reach the plate interface. They both present an 681 apparently sub-vertical distribution; however, no clear direction of migration in depth with time could 682 be identified within each individual cluster. By the end of the second cluster's occurrence, both groups $683 \# 1$ and \#2 cover a column at depths 10-30km aligned horizontally along the fault system F6, in an 684 almost linear 5-km-long segment oriented SW-NE (Fig.A.1b Profile 1). Although there is a partial 685 overlap between their epicenters, cluster \#1 appears to have occurred at the NW half of the activated 686 zone while cluster \#2 mainly occupies the SE half. during the next day (Fig.A.1a). A new burst of its activity was triggered by a couple of $M_{L}=3.9-4.0$ events on 5 April, with a rate of 2-3 events/day for the next 25 days. A stronger outbreak began on 23 May 2009, following an $M_{\mathrm{L}}=3.8$ event, starting with a rate of 25 events/day which slowly diminished, but the cluster remained active until the end of the study period, in September 2009. Due to the comparable magnitudes between the largest events of this cluster, it can be characterized as a swarm. Located $\sim 16 \mathrm{~km}$ SSE of clusters \#1 and \#2, and $\sim 10 \mathrm{~km} \mathrm{SE}$ of the slab fault F6, it fills the geographical gap between the two main patches that ruptured during the 2008 Methoni mainshock (Fig.4a). This group occurs within the overriding plate, mainly at depths between 10 and $15 \mathrm{~km}$ (Fig. A.1b Profile 2). clustering, but are composed of diffuse seismicity that generally delineates different regions of particular interest. slab fault F7 (Fig.4a). It is located at the borders of the higher slip area of the 2008 main rupture and relates geographically with the MT region across the whole panel (Fig.4a). This area includes almost all the largest aftershocks of the first period before our post-Methoni experiment (Fig.2a). It is 
distributed at depths between 10 and $20 \mathrm{~km}$, but is mostly concentrated at $14-15 \mathrm{~km}$, thus confined in the upper plate (Fig. A.1b Profiles 2 and 3). Its evolution in time exhibits an almost constant rate of 0.3-0.4 events/day with the exception of a small burst (10-17 April) including three $\mathrm{M}_{\mathrm{L}}=3.5$ events

708

709

710

711

712 (Fig. A.1a).

\section{Group \#5 orange}

Spatial group \#5 (orange) covers a $35 \mathrm{~km}$ x $15 \mathrm{~km}$ region of diffuse seismicity constrained at depths of $25-30 \mathrm{~km}$ (Fig. A.1b profiles 2,3), which corresponds to the lower plate oceanic crust. It presents a very low seismicity rate of 0.1-0.2 events/day throughout the study period (Fig. A.1a).

\section{Group \#6 cyan}

Spatial group \#6 (cyan) is located updip of the Methoni rupture, at the western part of the panel (Fig.4a). Though dispersed, it clearly follows the edges of the updip extent of the coseismic slip area, with focal depths mainly in the range $17-23 \mathrm{~km}$, mostly concentrated at $20 \mathrm{~km}$ depth (Fig. A.1b profiles 1,2 at distances $40-50 \mathrm{~km}$ along the $\mathrm{X}$ axis) hence right above the interplate boundary. Despite its low background rate, it also contains the strongest event of the study period, an $\mathrm{M}_{\mathrm{L}}=4.4$ earthquake that occurred on 21 April 2009 and caused a short outburst of $\sim 20$ events during the following 10 days, including an $\mathrm{M}_{\mathrm{L}}=4.0$ event on 27 April 2009 (Fig. A.1a). This episode took place half-way through the first period of activity at cluster \#3.

\section{Group \#7 black}

Lastly, spatial group \#7 (black) is located further NE, across-panel F6F7 in a NW-SE direction reaching slab fault F6 at about the same place as clusters \#1 and \#2, with its focal depths being distributed in the range $23-30 \mathrm{~km}$ (Fig. A.1b, profiles 1-3). This group does not present any significant bursts of activity, but rather a constant seismicity rate of $\sim 0.2$ events/day which appears to slightly increase to 0.5 events/day after the initiation of cluster \#3 in April 2009 (Fig. A.1a).

Besides the activity in panel F6F7, the rest of the study area (background seismicity) contains hypocenters spreading in a wide depth range (10-30km) (Fig.3a) and exhibits a seismicity rate of 1-2 events/day. Beneath Matapan Trough (MT), the hypocenters are mainly located in the upper plate apart from those along panel F6F7 and its vicinity for which also the lower plate presents some activity (Fig. A.1c). Hypocentral distribution along MT from our 1-year-long experiment, shows no 

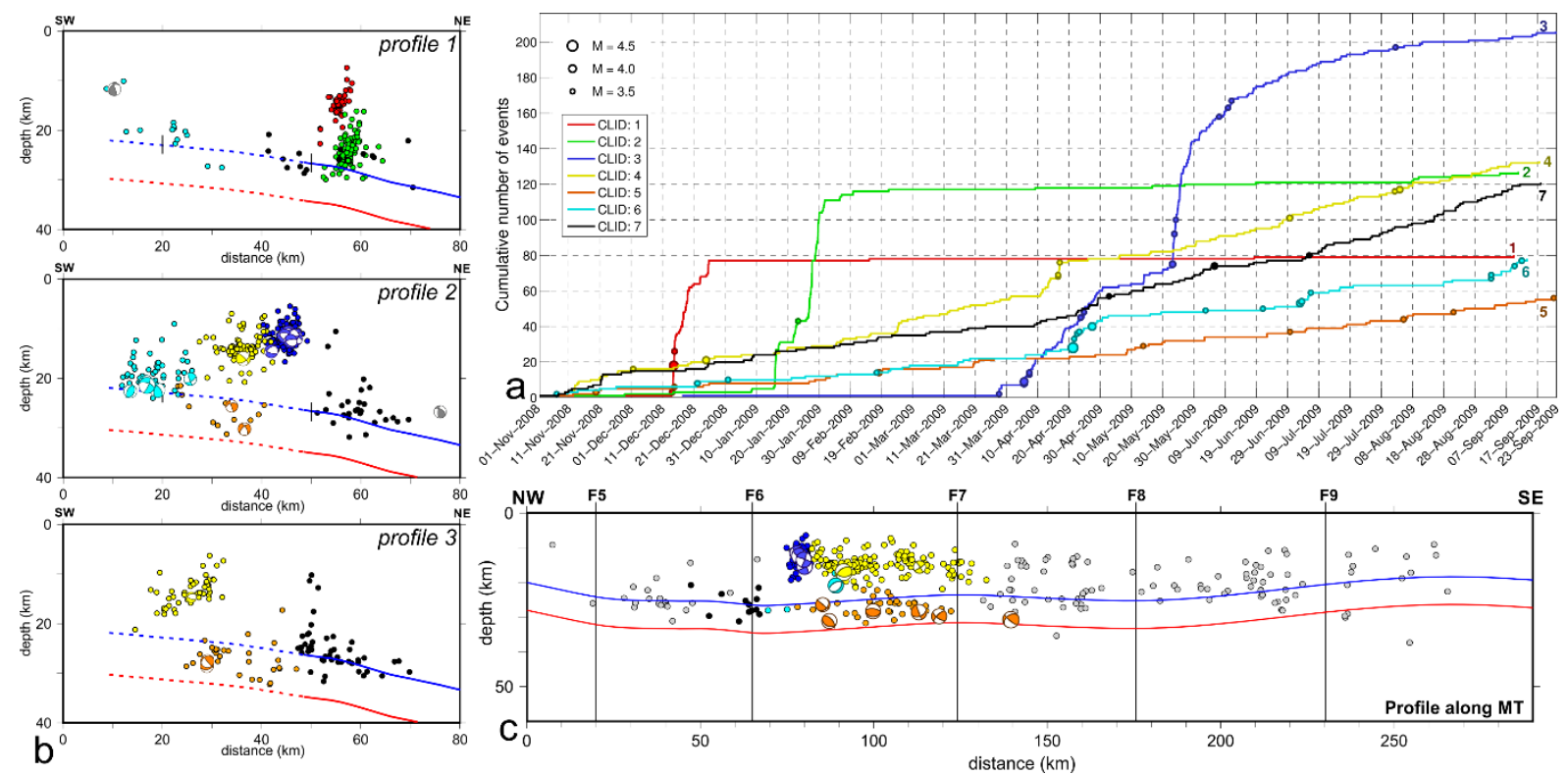

737 Fig. A.1 Spatiotemporal analysis results and seismicity cross section along the Matapan Trough. (a)

738 Cumulative number of events per spatial group for the post-Methoni experiment in panel F6F7.

739 Different colors correspondent to the different spatial group, also represented by a cluster ID (1-7)

740 similarly to Fig.4a. The larger events (Ml>3.5) are marked with circles, with their size being

741 proportional to the magnitude (b) Cross-sections of the clustered relocated hypocenters within panel

742 F6F7, (top) profile 1: along slab fault F6, (middle) profile 2: central part and (bottom) profile 3:

743 eastern part of panel F6F7. The two black vertical ticks on the blue lines of panel (b) at horizontal

744 distances of 20 and $50 \mathrm{~km}$ are denoting the 30-km-downdip mainshock rupture width along the western part of panel F6F7 (see also Fig. 4b). Beachballs present the far-hemisphere projections of selected focal mechanisms, with their compressive quadrants following the same colourcoding as the hypocenters of the respective spatial groups. (c) $20 \mathrm{~km}$-wide cross-section of relocated hypocenters projected along the MT (black dashed NW-SE-trending line in Fig.3a). The continuous vertical lines denote the location of the slab faults from Sachpazi et al., 2016b). Blue and red solid lines in panels (b) and (c) are for the top and base of the lower plate crust proposed by RF 
752 prolongation, proposed by this study, assuming an $8 \mathrm{~km}$ thick oceanic crust (Gesret et al., 2010). The

753 plate interface depth southeastwards of slab fault F8 is obtained from a recently acquired seismic 754 profile west of Crete (Hussni et al., 2017). 